syn with respect to the $\mathrm{C}=\mathrm{C}$ bond (Leiserowitz, 1976). In this respect, it resembles the 3,4-methylenedioxy and 3,4-dimethoxy acids but not the 3,4-dihydroxy derivative which adopts the anti conformation (GarciaGranda, Beurskens, Beurskens, Krishna \& Desiraju, 1987). The phenyl ring is almost planar $\left(\chi^{2}=20.4\right)$ and makes an angle of $4.0(1)^{\circ}$ with the carboxyl group, in agreement with related structures. Salient geometrical details of these structures may be found in the deposited material.

The crystal structure is typical of the $\gamma$ family. Centrosymmetrically-related molecules are strongly

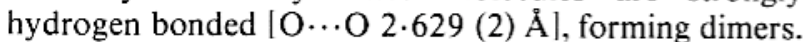
These dimers are stacked in the short axis separation (4.64 $\AA$ ). The crystal therefore belongs to the $\gamma$ domain and is predictably stable to solid-state UV irradiation $(\lambda>300 \mathrm{~nm}$ ) (Desiraju, Kamala, Kumari \& Sarma, 1984). Such behaviour is normal. It might be noted, in this connection, that 4-formylcinnamic acid, which has a similar $\gamma$ structure (short axis $4.825 \AA$ ), exhibits anomalous solid-state photoreactivity (Nakanishi \& Hasegawa, 1985).

The carboxyl oxygen $\mathrm{O}(1)$ is hydrogen-bonded $(2 \cdot 869 \AA)$ to the phenolic oxygen $\mathrm{O}(4)$ of the $n$-glide related molecule $\left(-\frac{1}{2}+x, \frac{1}{2}-y, \frac{1}{2}+z\right)$. This scheme of hydrogen bonding has been observed in 3-coumaric acid (Raghunathan \& Pattabhi, 1981). Further, the molecules are stabilized by infinite zigzag chains of $\mathrm{O}-\mathrm{H} \cdots \mathrm{O}$ and $\mathrm{C}-\mathrm{H} \cdots \mathrm{O}$ hydrogen bonds. The relevant
C...O distances for the latter are: $\mathrm{O}(4) \cdots \mathrm{C}(10)\left(1 \frac{1}{2}-x\right.$, $\left.\frac{1}{2}+y, \frac{1}{2}-z\right) 3 \cdot 394$ (3) $\AA$; $\mathrm{O}(2) \cdots \mathrm{C}(10)\left(\frac{1}{2}-x,-\frac{1}{2}+y\right.$, $\left.\frac{1}{2}-z\right) 3 \cdot 177$ (3) $\AA$. The angular approaches of the atoms are favourable for $\mathrm{C}-\mathrm{H} \cdots \mathrm{O}$ bonding (Taylor \& Kennard, 1984).

MN thanks the CSIR, New Delhi, for financial assistance.

\section{References}

Desiraju, G. R., Kamala, R., Kumari, B. H. \& Sarma, J. A. R. P. (1984). J. Chem. Soc. Perkin Trans. 2, pp. 181-189.

Garcia-Granda, S., Beurskens, G., Beurskens, P. T., Krishna, T. S. R. \& Desiraju, G. R. (1987). Acta Cryst. C43, 683-685.

LeISEROWITZ, L. (1976). Acta Cryst. B32, 775-802.

Main, P., Fiske, S. J., Hull, S. E., Lessinger, L., Germain, G., DeclercQ, J.-P. \& WoOlfson, M. M. (1980). MULTAN80. A System of Computer Programs for the Automatic Solution of Crystal Structures from X-ray Diffraction Data. Univs. of York, England, and Louvain, Belgium.

NaKanishi, H. \& Hasegawa, M. (1985). Acta Cryst. C41, 70-71. Raghunathan, S. \& Pattabhi, V. (1979). Acta Cryst. B35, 214-215.

Raghunathan, S. \& Pattabhi, V. (1981). Acta Cryst. B37, 1299-1301.

Sarma, J. A. R. P. \& Desiraju, G. R. (1986). Acc. Chem. Res. 19. $222-228$.

SCHMidT, G. M. J. (1964). J. Chem. Soc. pp. 2014-2021.

SHeldrick, G. M. (1976). SHELX76. Program for crystal structure determination. Univ. of Cambridge, England.

TAYLOR, R. \& KenNARd, O. (1984). Acc. Chem. Res. 17, 320-326.

Acta Cryst. (1988). C44, 277-279

\title{
X-ray Structure of 1,4-Bis(diphenylphosphino)butane
}

\author{
By A. Valentina Rivera, Dora Gómez C., Eldrys Rodulfo de Gil* and Trino Suárez \\ Departamento de Química, Facultad de Ciencias, Universidad de los Andes, Mérida, Venezuela
}

(Received 25 November 1986; accepted 14 September 1987)

\begin{abstract}
C}_{28} \mathrm{H}_{28} \mathrm{P}_{2}, M_{r}=426 \cdot 48$, monoclinic, $P 22_{1} / c$, $a=6.134(2), \quad b=8 \cdot 166(3), c=24.634$ (5) $\AA, \quad \beta=$ $106.4(2)^{\circ}, \quad V=1184 \AA^{3}, \quad Z=2, \quad D_{m}=1 \cdot 20, \quad D_{x}=$ $1.196 \mathrm{~g} \mathrm{~cm}^{-3}, \lambda($ Mo $K \alpha)=0.71069 \AA, \mu=1.55 \mathrm{~cm}^{-1}$, $F(000)=452, T=295 \mathrm{~K}, R=0.051$ for 924 unique reflections with $I>3 \sigma(I)$. The structure found for the free ligand is very similar to that reported for the one coordinated to $\mathrm{Rh}$ atoms in $\left[\mathrm{Rh}_{2}\left\{\mathrm{Ph}_{2} \mathrm{P}\left(\mathrm{CH}_{2}\right)_{4} \mathrm{PPh}_{2}\right\}\right.$ $\left(\eta-\mathrm{C}_{5} \mathrm{H}_{5}\right)_{2}(\mathrm{CO})_{2}$ ], the only known $\mathrm{X}$-ray determination of this ligand. The $-\left(\mathrm{CH}_{2}\right)_{4}-$ moiety is planar within $0.004(5) \AA$ with the $\mathrm{P}$ atoms $+0.105(2)$ and

atoms have the usual distorted tetrahedral configuration.

Introduction. Metal complexes with polydentate phosphines are becoming increasingly important due to their implication in catalytic reactions. Our current interest in the synthesis and catalytic properties of $\mathrm{Ru}$ complexes with polydentate phosphines led us to the study of the $\mathrm{Ph}_{2} \mathrm{P}\left(\mathrm{CH}_{2}\right)_{4} \mathrm{PPh}_{2}$ ligand and its $\mathrm{Ru}$ complexes. Here we report the $\mathrm{X}$-ray determination of the free ligand.
\end{abstract} -0.105 (2) $\AA$ from its calculated mean plane. The P

* To whom correspondence should be addressed.

0108-2701/88/020277-03\$03.00
Experimental. Density determined by flotation in nitrobenzene. Greenish transparent parallelepiped c 1988 International Union of Crystallography 
crystal $0.3 \times 0.3 \times 0.4 \mathrm{~mm}$. Automated four-circle Philips PW 1100 diffractometer. Lattice parameters determined by least-squares procedure applied to the setting angles of 25 strong reflections in the range $3<\theta<6^{\circ}$. Intensity data up to $(\sin \theta) / \lambda=0.668 \AA^{-1}$ in the range $-6 \leq h \leq 6,0 \leq k \leq 9,0 \leq l \leq 28$ measured with graphite-monochromated Mo $K \alpha$ radiation. Systematic absences proved the space group to be $P 2{ }_{1} / c$. After $\mathrm{Lp}$ corrections the initial 2258 reflections were reduced to 924 unique data with $I>3 \sigma(I)$. Number of unobserved reflections: 368 . No corrections for absorption or extinction. Three standard reflections, no intensity variation. Structure solved by direct methods (MULTAN77; Main, Lessinger, Woolfson, Germain \& Declercq, 1977) with part of the molecule taken into account. The structure refined by full-matrix least squares with isotropic temperature factors for all non- $\mathrm{H}$ atoms converged to $R=0.213$. All $\mathrm{H}$ atoms were placed in geometrically calculated positions and refined as rigid groups with the constraint that all $\mathrm{C}-\mathrm{H}=1.00 \AA$ and one overall isotropic temperature factor. All non-H atoms were refined anisotropically. Final anisotropic-isotropic refinement converged to $R=0.051$ and $w R=0.052$ with $(\Delta / \sigma)_{\max }=0.001$. Maximum and minimum heights in final difference Fourier synthesis were +0.33 and -0.33 e $\AA^{-3}$. Complex neutral atomic scattering factors from International Tables for X-ray Crystallography (1974). The function minimized was $\sum w\left(\left|F_{o}\right|-\left|F_{c}\right|\right)^{2}$ where $w=1 /\left[\sigma^{2}\left(F_{o}\right)+g F_{o}{ }^{2}\right]$ and $g$ converged to 0.000283 . All calculations performed with the SHELX77 system (Sheldrick, 1977) on a Burroughs B5900 computer at the Universidad de los Andes.

Discussion. Positional and equivalent isotropic thermal parameters and the resulting bond lengths and angles are given in Tables 1 and 2, respectively.* Fig. 1 shows a perspective view of the molecule. $\mathrm{Ph}_{2} \mathrm{P}\left(\mathrm{CH}_{2}\right)_{4} \mathrm{PPh}_{2}$ in the solid state consists of discrete molecules sitting on a crystallographic inversion centre (1) which relates one half of the molecule to the other half. The $-\left(\mathrm{CH}_{2}\right)_{4}$ moiety is planar within $0.004(5) \AA$, with $\mathrm{C}-\mathrm{C}-\mathrm{C}$ bond angle of expected value $\mid 109.2(7)^{\circ}$ |. Its $\mathrm{C}-\mathrm{C}$ bond lengths of $1.523(7)$ and $1.619(9) \AA$ are significantly different, the longer being the one where the $\bar{l}$ is located. This anisotropy is also observed in $\left[\mathrm{Rh}_{2}\right.$ $\left.\left\{\mathrm{Ph}_{2} \mathrm{P}\left(\mathrm{CH}_{2}\right)_{4} \mathrm{PPh}_{2}\right\}\left(\eta-\mathrm{C}_{5} \mathrm{H}_{5}\right)_{2}(\mathrm{CO})_{2}\right]$ (Faraone, Bruno, Tresoldi, Faraone \& Bombieri, 1981), the only X-ray determination so far known of a $\mathrm{Ph}_{2} \mathrm{P}\left(\mathrm{CH}_{2}\right)_{4} \mathrm{PPh}_{2}$ complex, with reported values of $1.51(1)$ and

* Lists of anisotropic thermal parameters, H-atom coordinates refined as rigid groups, mean-plane calculations, torsion angles and structure factors have been deposited with the British Library Document Supply Centre as Supplementary Publication No. SUP 44366 (10 pp.). Copies may be obtained through The Executive Secretary, International Union of Crystallography, 5 Abbey Square, Chester CH1 2HU, England.
Table 1. Atomic positional parameters $\left(10^{4}\right)$ and equivalent isotropic temperature factors $\left(\AA^{2} \times 10^{3}\right)$

$\begin{array}{lcccc} & x & y & z & U_{\mathrm{eq}}{ }^{*} \\ \mathrm{P} & 3173(2) & 3438(2) & 9165(1) & 55 \\ \mathrm{C}(1) 1 & 4282(9) & 2407(6) & 8172(2) & 57 \\ \mathrm{C}(1) 2 & 3890(12) & 1576(8) & 7668(2) & 72 \\ \mathrm{C}(1) 3 & 1965(15) & 696(9) & 7468(3) & 83 \\ \mathrm{C}(1) 4 & 393(11) & 623(8) & 7765(3) & 85 \\ \mathrm{C}(1) 5 & 771(9) & 1487(7) & 8273(2) & 68 \\ \mathrm{C}(1) 6 & 2750(9) & 2378(6) & 8484(2) & 48 \\ \mathrm{C}(2) 1 & 7240(10) & 5287(7) & 9309(2) & 66 \\ \mathrm{C}(2) 2 & 8428(10) & 6654(8) & 9231(2) & 73 \\ \mathrm{C}(2) 3 & 7322(14) & 7924(7) & 8906(3) & 74 \\ \mathrm{C}(2) 4 & 5012(12) & 7817(7) & 8663(2) & 70 \\ \mathrm{C}(2) 5 & 3833(10) & 6462(7) & 8744(2) & 57 \\ \mathrm{C}(2) 6 & 4929(9) & 5161(6) & 9067(2) & 48 \\ \mathrm{C}(1) & 5249(9) & 2084(6) & 9641(2) & 58 \\ \mathrm{C}(2) & 4075(9) & 557(6) & 9777(2) & 61\end{array}$

Table 2. Bond lengths $(\AA)$ and angles $\left(^{\circ}\right)$

$\begin{array}{llll}\mathrm{C}(1) 6-\mathrm{P} & 1.839(5) & \mathrm{C}(2) 1-\mathrm{C}(2) 2 & 1.376(7) \\ \mathrm{C}(2) 6-\mathrm{P} & 1.829(5) & \mathrm{C}(2) 1-\mathrm{C}(2) 6 & 1.378(7) \\ \mathrm{C}(1)-\mathrm{P} & 1.838(5) & \mathrm{C}(2) 2-\mathrm{C}(2) 3 & 1.367(7) \\ \mathrm{C}(1) 1-\mathrm{C}(1) 2 & 1.375(7) & \mathrm{C}(2) 3-\mathrm{C}(2) 4 & 1.377(8) \\ \mathrm{C}(1) 1-\mathrm{C}(1) 6 & 1.373(7) & \mathrm{C}(2) 4-\mathrm{C}(2) 5 & 1.367(7) \\ \mathrm{C}(1) 2-\mathrm{C}(1) 3 & 1.351(8) & \mathrm{C}(2) 5-\mathrm{C}(2) 6 & 1.383(6) \\ \mathrm{C}(1) 3-\mathrm{C}(1) 4 & 1.366(8) & \mathrm{C}(1)-\mathrm{C}(2) & 1.523(7) \\ \mathrm{C}(1) 4-\mathrm{C}(1) 5 & 1.399(8) & \mathrm{C}(2)-\mathrm{C}\left(2^{\prime}\right) & 1.619(9) \\ \mathrm{C}(1) 5-\mathrm{C}(1) 6 & 1.384(7) & & \\ \mathrm{C}(1) 6-\mathrm{P}-\mathrm{C}(2) 6 & 100.3(2) & \mathrm{C}(2) 2-\mathrm{C}(2) 1-\mathrm{C}(2) 6 & 121.4(5) \\ \mathrm{C}(1) 6-\mathrm{P}-\mathrm{C}(1) & 101.1(2) & \mathrm{C}(2) 1-\mathrm{C}(2) 2-\mathrm{C}(2) 3 & 120.2(6) \\ \mathrm{C}(2) 6-\mathrm{P}-\mathrm{C}(1) & 102.7(2) & \mathrm{C}(2) 2-\mathrm{C}(2) 3-\mathrm{C}(2) 4 & 119.1(6) \\ \mathrm{C}(1) 2-\mathrm{C}(1) 1-\mathrm{C}(1) 6 & 121.6(5) & \mathrm{C}(2) 3-\mathrm{C}(2) 4-\mathrm{C}(2) 5 & 120.7(5) \\ \mathrm{C}(1) 1-\mathrm{C}(1) 2-\mathrm{C}(1) 3 & 120.3(6) & \mathrm{C}(2) 4-\mathrm{C}(2) 5-\mathrm{C}(2) 6 & 121.0(5) \\ \mathrm{C}(1) 2-\mathrm{C}(1) 3-\mathrm{C}(1) 4 & 120.3(6) & \mathrm{C}(2) 1-\mathrm{C}(2) 6-\mathrm{C}(2) 5 & 117.7(5) \\ \mathrm{C}(1) 3-\mathrm{C}(1) 4-\mathrm{C}(1) 5 & 119.6(6) & \mathrm{P}-\mathrm{C}(2) 6-\mathrm{C}(2) 1 & 125.0(4) \\ \mathrm{C}(1) 4-\mathrm{C}(1) 5-\mathrm{C}(1) 6 & 120.5(6) & \mathrm{P}-\mathrm{C}(2) 6-\mathrm{C}(2) 5 & 117.3(4) \\ \mathrm{P}-\mathrm{C}(1) 6-\mathrm{C}(1) 1 & 124.1(4) & \mathrm{P}-\mathrm{C}(1)-\mathrm{C}(2) & 110.3(3) \\ \mathrm{P}-\mathrm{C}(1) 6-\mathrm{C}(1) 5 & 118.2(4) & \mathrm{C}(1)-\mathrm{C}(2)-\mathrm{C}(2) & 109.2(7) \\ \mathrm{C}(1) 1-\mathrm{C}(1) 6-\mathrm{C}(1) 5 & 117.7(5) & & \end{array}$

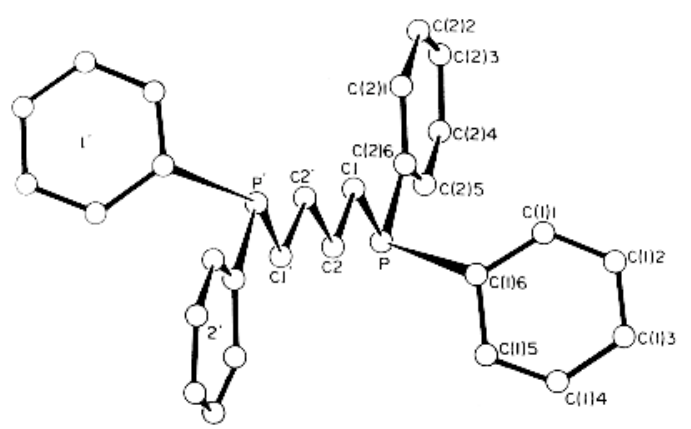

Fig. 1. Perspective view of the molecule showing atom numbering.

1.60 (2) $\AA$ for $(\mathrm{Bu}) \mathrm{C}-\mathrm{C}(\mathrm{Bu})$ distances. The $\mathrm{P}$ atoms are at $+0.105(2)$ and $-0.105(2) \AA$ from the $-\left(\mathrm{CH}_{2}\right)_{4}-$ calculated mean plane. The $\mathrm{P}$ atoms have the usual distorted tetrahedral configuration with $(\mathrm{Ph}) \mathrm{C}-\mathrm{P}-\mathrm{C}(\mathrm{Ph})$ angle of $100 \cdot 3(2)^{\circ}$ and $(\mathrm{Bu}) \mathrm{C}-$ $\mathrm{P}-\mathrm{C}(\mathrm{Ph})$ angles of $101.1(2)$ and $102.7(2)^{\circ}$.

The phenyl rings are planar within 0.009 (6) $\AA$ with the $\mathrm{P}$ atom coplanar to both of them. The dihedral 
angle between them, $94^{\circ}$, is in the reported range of other $\mathrm{Ph}_{2} \mathrm{P}-R-\mathrm{PPh}_{2}$ ligands $\left[73 \cdot 5-107 \cdot 6^{\circ}\right.$ for $R$ $=-\left(\mathrm{CH}_{2}\right)_{2}-\mathrm{l}$ though wider than that reported for $\left.\mid \mathrm{Rh}_{2}\left\{\mathrm{Ph}_{2} \mathrm{P}\left(\mathrm{CH}_{2}\right)_{4} \mathrm{PPh}_{2}\right\}\left(\eta-\mathrm{C}_{5} \mathrm{H}_{5}\right)_{2}(\mathrm{CO})_{2}\right]\left(70 \cdot 2^{\circ}\right)$. The $(\mathrm{Ph}) \mathrm{C}-\mathrm{C}(\mathrm{Ph})$ distances are in the range $1.351(8)$ $1.399(8) \AA$ with mean value of $1.380 \AA$. $(\mathrm{Ph}) \mathrm{C}-$ $\mathrm{C}(\mathrm{Ph})-\mathrm{C}(\mathrm{Ph})$ angles are in the range $117.7(5)-$ $121.6(5)^{\circ}$ with the angle centered on $\mathrm{C}$ atoms bonded to $\mathrm{P}\left[117.7(5)^{\circ} \mid\right.$ presenting its usual characteristic of being less than $120^{\circ}$ (Rivera, Rodulfo de Gil \& Fontal, 1985).

The $(\mathrm{Bu}) \mathrm{C}-\mathrm{P}$ distance $|1.838(5) \AA ̊|$ can be considered identical to the two $(\mathrm{Ph}) \mathrm{C}-\mathrm{P}$ bonds $[1.829(5)$ and 1.839 (5) Ål.

The authors are grateful to the CDCH-ULA and CONICIT-Venezuela (grants C-81-77 and S1-1863) for financial support and to the CEDEC-ULA for the allocated time.

\section{References}

Faraone, F., Bruno, G., Tresoldi, G., Faraone, G. \& Bombieri, G. (1981). J. Chem. Soc. Dalton Trans. pp. $1651-1656$.

International Tables for X-ray Crystallography (1974). Vol. IV Birmingham: Kynoch Press. (Present distributor D. Reidel, Dordrecht.)

Main, P., Lessinger, L., Woolfson, M. M., Germain, G. \& DeClerCQ, J.-P. (1977). MULTAN77. A System of Computer Programs for the Automatic Solution of Crystal Structures from $X$-ray Diffraction Data. Univs. of York, England, and Louvain, Belgium.

Rivera, A. V., Rodulfo de Gil, E. \& Fontal, B. (1985). Inorg. Chim. Acta, 98, 153-160.

SheldRICK, G. M. (1977). SHELX77. Program for crystal structure determination. Univ, of Cambridge, England.

Acta Cryst. (1988). C44, 279-281

\title{
Structure of 3,3-Diphenyltetrahydrofuran
}

\author{
By Beverly R. Vincent and T. Stanley Cameron* \\ Department of Chemistry, Dalhousie University, Halifax, Nova Scotia, Canada B3H $4 J 3$
}

(Received 28 August 1987; accepted 21 September 1987)

\begin{abstract}
C}_{16} \mathrm{H}_{16} \mathrm{O}, M_{r}=224 \cdot 3$, monoclinic, $P 2_{1}, a$ $=9.252(3), \quad b=7.060(5), \quad c=10.246(3) \AA, \quad \beta=$ $112.65(3)^{\circ}, \quad V=617.6(5) \AA^{3}, \quad Z=2, \quad D_{x}=$ $1.206 \mathrm{Mg} \mathrm{m}^{-3}, \lambda\left(\mathrm{Mo} K \alpha_{1}\right)=0.70926 \AA, \mu=0.39 \mathrm{~mm}^{-1}$ $F(000)=240, T=293 \mathrm{~K}, R=0.049$ for $1257 \mathrm{ob}$ served reflections. The phenyl-substituted carbon in the furan ring is above the plane formed by the other four members of the ring. The planes of the two phenyl rings meet at an angle of $77^{\circ}$ and make angles of 153 and $82^{\circ}$ with the best plane of the furan ring. The bis-benzylic $\mathrm{C}-\mathrm{C}$ bond forms an angle of $62^{\circ}$ with the plane of one of the phenyl rings.
\end{abstract}

Introduction. The interest in the structure of 3,3 diphenyltetrahydrofuran (I) arises from its photosensitized (electron-transfer) reaction (Arnold, Fahie, Lamont, Wierzchowski \& Young, 1987) using 1,4-dicyanobenzene as an electron-accepting photosensitizer and acetonitrile-methanol as solvent. The radical cation of (I) should be able to attain a conformation which would allow sufficient overlap of the SOMO, associated primarily with the diphenylmethyl moiety, with the $\sigma$-orbital of the benzylic $\mathrm{C}-\mathrm{C}$ bond so that cleavage will occur. The objective of the present $\mathrm{X}$-ray structure

* Author to whom correspondence should be addressed. 0108-2701/88/020279-03\$03.00 analysis is to determine the preferred conformation of (I) in the solid state in order to determine the potential for orbital overlap.

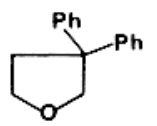

(1)

Experimental. Crystals provided by D. R. Arnold and L. J. Lamont, Department of Chemistry, Dalhousie University, grown from $95 \%$ ethanol. CAD-4 diffractometer, crystal dimensions $0.2 \times 0.3 \times 0.3 \mathrm{~mm}$, graphite-monochromatized radiation, cell parameters refined from $\theta$ values of 25 reflections $\left(10 \leq \theta \leq 14^{\circ}\right)$, $\omega-2 \theta$ scans, three standard reflections $(401, \overline{2} 32,104)$, $<2 \%$ intensity variation. Intensities reduced to a standard scale using routine procedures (Cameron \& Cordes, 1979). Corrections for Lorentz and polarization factors applied, but no corrections made for absorption or extinction. 1558 reflections, $2 \theta<50^{\circ}$ [ $h-11$ to $11, k-1$ to $8, l 0$ to $12,1257(81 \%)$ with $I \geq 3 \sigma(I), R_{\text {int }}=0.0161$.

Structure solved by a multisolution application of the tangent formula (Karle \& Hauptman, 1958) using (c) 1988 International Union of Crystallography 